\title{
Improving the economic efficiency of Russian industrial enterprises
}

\author{
Maria Mechikova ${ }^{1, *}$, Nataliya Zemlyakova ${ }^{2}$, and Ekaterina Medjuha ${ }^{2}$ \\ ${ }^{1}$ TPI DSTU Branch, Economics and management Department, 347904, Taganrog, Russia \\ ${ }^{2}$ DSTU, Finance and credit Department, 344000, Rostov-on-Don, Russia
}

\begin{abstract}
This study is devoted to the study of the current state of the industry in Russia, the identification of positive and negative trends in the development of domestic industry, the development of a system of indicators that reflect the effectiveness of individual industrial enterprises, as well as the development of proposals to improve their economic efficiency.
\end{abstract}

In modern realities, the question of the need to stimulate investment in the modernization of the Russian industry and import substitution is becoming more urgent. Technical backwardness, outdated technologies, morally and physically worn-out equipment prevent Russian industrial enterprises to work with a sufficient degree of efficiency and produce a competitive product. At the state level, in the current conditions of the aggravated economic situation, the state declared its intention to implement measures to stimulate investment in the interests of technological modernization and renewal of industry.

In the research of domestic and foreign scientists, special attention is devoted to improving the efficiency of industrial enterprises. The founders of the contemporary approach to understanding these problems are I. Schumpeter, Kondratyev, H., Hattori Toshio, U. Baumol, Y. Wang, Dane X. straight ahead, Ben, K. Freeman, A., Kleinknecht, John. Clark, L. Sute, C. Davis, E. mensfield, A. Romeo, P. Solow, F. Hayek, J. von Neumann, P. F. Harrod.

Theoretical and methodological basis of research is the theoretical development of the well-known Russian and foreign economists, such as S. P. Aukutsionek, D. I. Daugavet, P. S. Zavyalov And R. Kapelyushnikov, G. B. Kleiner, V. P. Kryuchkov, A. N. Litvinenko, M. M. Maksimov, A. K. Petelin I. S. Semenenko, I. P. Sokolova, I. V. Sedov, V. L. Tambovtsev, V. A. Swander, A. E. Shastitko, A. E. Yakunichev and other prominent scholars and practitioners.

Studies of foreign scientists in this field are wide and varied, but the application of their results may not be fully relevant for Russia, which has other geopolitical and economic conditions.

At the same time, the problem of systematization of economic and theoretical tools for analyzing long-term growth factors and improving the efficiency of both the national

\footnotetext{
${ }^{*}$ Corresponding author: mashanovi@yandex.ru
} 
industry as a whole and the efficiency of individual industrial enterprises remains open until now.

All of the above determines the relevance of the chosen research topic.

The aim of the research is to study the approaches and methods of increasing the efficiency of Russian industrial enterprises.

Achieving this goal requires solving the following tasks:

- to investigate the dynamics and assess the current state of Russian industrial enterprises;

- identify indicators that determine the efficiency of industrial enterprises;

- track positive and negative trends in the development of domestic industry;

- $\quad$ suggest ways and methods to improve the economic efficiency of production.

Russia is a country with a developed industry. It accounts for $3 / 5$ of the total gross social product, more than $2 / 5$ of the national income, about $1 / 2$ of the production fixed assets and, together with the construction of about $2 / 5$ of the population engaged in social production. Industry primarily determines the production, scientific and technical potential, the degree and effectiveness of the use of natural, material and labor resources. It serves as the basis for the formation of territorial-industrial complexes.

In the composition of the industry, the intensity of the development of individual industries is different, due to the peculiarities of their formation in the past, the need to comply with certain inter-sectoral proportions, the requirements of scientific and technological progress and other reasons.

As for the dynamics of industrial development, in General, they are developing quite effectively. Industrial production index in 2017. compared to 2016 . it made $101,0 \%$, in December, 2017. compared to December 2016. - 98.5\%, compared to November 2017. $108.2 \%$.

The indices of industrial production from 2015 to 2017 in relation to the indicators of 2014 are presented in table 1[2].

Table 1. Russian industrial production indices as \% of the average monthly value of 2014

\begin{tabular}{|c|c|c|c|c|c|}
\hline & \multicolumn{5}{|c|}{ In $\%$ to } \\
\hline & \multirow{2}{*}{$\begin{array}{c}\text { By } \\
\text { corresponding } \\
\text { period of a } \\
\text { previous year }\end{array}$} & \multicolumn{2}{|c|}{ To previous period } & \multicolumn{2}{|c|}{$\begin{array}{c}\text { To the average monthly } \\
\text { value of } 2014\end{array}$} \\
\hline & & Actually & $\begin{array}{c}\text { With an } \\
\text { exception } \\
\text { seasonal } \\
\text { and } \\
\text { calendar } \\
\text { factors }\end{array}$ & Actually & $\begin{array}{l}\text { With an } \\
\text { exception } \\
\text { seasonal } \\
\text { and } \\
\text { calendar } \\
\text { factors }\end{array}$ \\
\hline \multicolumn{6}{|c|}{2016} \\
\hline January & 99,2 & $\begin{array}{r}74 \\
7\end{array}$ & $\begin{array}{r}98, \\
7\end{array}$ & $\begin{array}{r}88, \\
2\end{array}$ & $\begin{array}{r}98, \\
8\end{array}$ \\
\hline February & 103,8 & $\begin{array}{r}10 \\
4,4\end{array}$ & $\begin{array}{r}103 \\
, 1\end{array}$ & $\begin{array}{r}92 \\
1\end{array}$ & $\begin{array}{r}101 \\
, 9\end{array}$ \\
\hline March & 100,3 & $\begin{array}{r}10 \\
8,8\end{array}$ & $\begin{array}{r}98, \\
1\end{array}$ & $\begin{array}{r}10 \\
0,2\end{array}$ & $\begin{array}{r}100 \\
, 0\end{array}$ \\
\hline I quarter & 101,1 & $\begin{array}{r}84 \\
4\end{array}$ & & & \\
\hline April & 101,0 & $\begin{array}{r}96, \\
3\end{array}$ & $\begin{array}{r}99 \\
6\end{array}$ & $\begin{array}{r}96 \\
4\end{array}$ & $\begin{array}{r}99 \\
6\end{array}$ \\
\hline May & 101,5 & 98 & 99 , & 94 & 98 \\
\hline
\end{tabular}




\begin{tabular}{|c|c|c|c|c|c|}
\hline & \multicolumn{5}{|c|}{ In $\%$ to } \\
\hline & \multirow{2}{*}{$\begin{array}{c}\text { By } \\
\text { corresponding } \\
\text { period of a } \\
\text { previous year }\end{array}$} & \multicolumn{2}{|c|}{ To previous period } & \multicolumn{2}{|c|}{$\begin{array}{c}\text { To the average monthly } \\
\text { value of } 2014\end{array}$} \\
\hline & & Actually & $\begin{array}{l}\text { With an } \\
\text { exception } \\
\text { seasonal } \\
\text { and } \\
\text { calendar } \\
\text { factors }\end{array}$ & Actually & $\begin{array}{l}\text { With an } \\
\text { exception } \\
\text { seasonal } \\
\text { and } \\
\text { calendar } \\
\text { factors }\end{array}$ \\
\hline & & 1 & 1 & 5 & 7 \\
\hline June & 102,0 & $\begin{array}{r}10 \\
3,8\end{array}$ & $\begin{array}{r}101 \\
, 2\end{array}$ & $\begin{array}{r}98, \\
1\end{array}$ & $\begin{array}{r}99 \\
9\end{array}$ \\
\hline II quarter & 101,5 & $\begin{array}{r}10 \\
3,1\end{array}$ & & & \\
\hline $\begin{array}{l}\text { I half a } \\
\text { year }\end{array}$ & 101,3 & & & & \\
\hline July & 101,4 & $\begin{array}{r}99 \\
9\end{array}$ & $\begin{array}{r}100 \\
, 4\end{array}$ & $\begin{array}{r}98, \\
0\end{array}$ & $\begin{array}{r}100 \\
, 3\end{array}$ \\
\hline August & 101,5 & $\begin{array}{r}10 \\
1,5\end{array}$ & $\begin{array}{r}100 \\
, 1\end{array}$ & $\begin{array}{r}99 \\
5\end{array}$ & $\begin{array}{r}100 \\
, 4\end{array}$ \\
\hline September & 100,1 & $\begin{array}{r}10 \\
1,7\end{array}$ & $\begin{array}{r}99 \\
8\end{array}$ & $\begin{array}{r}10 \\
1,2\end{array}$ & $\begin{array}{r}100 \\
, 2\end{array}$ \\
\hline $\begin{array}{c}\text { III } \\
\text { quarter }\end{array}$ & 101,0 & $\begin{array}{r}10 \\
3,3\end{array}$ & & & \\
\hline $\begin{array}{l}\text { January - } \\
\text { September }\end{array}$ & 101,2 & & & & \\
\hline October & 101,6 & $\begin{array}{r}10 \\
6,6\end{array}$ & $\begin{array}{r}100 \\
, 7\end{array}$ & $\begin{array}{r}10 \\
7,9\end{array}$ & $\begin{array}{r}100 \\
, 9\end{array}$ \\
\hline November & 103,4 & $\begin{array}{r}10 \\
3,6\end{array}$ & $\begin{array}{r}102 \\
, 0\end{array}$ & $\begin{array}{r}11 \\
1,8\end{array}$ & $\begin{array}{r}102 \\
, 9\end{array}$ \\
\hline December & 100,2 & $\begin{array}{r}10 \\
5,8\end{array}$ & $\begin{array}{r}98, \\
1\end{array}$ & $\begin{array}{r}11 \\
8,3\end{array}$ & $\begin{array}{r}101 \\
, 0\end{array}$ \\
\hline$I V$ quarter & 101,7 & $\begin{array}{r}11 \\
3,1\end{array}$ & & & \\
\hline Year & 101,3 & & & & \\
\hline \multicolumn{6}{|c|}{2017} \\
\hline January & 102,3 & $\begin{array}{r}76, \\
2\end{array}$ & $\begin{array}{r}100 \\
, 4\end{array}$ & $\begin{array}{r}90, \\
2\end{array}$ & $\begin{array}{r}101 \\
, 4\end{array}$ \\
\hline February & 97,3 & $\begin{array}{r}99 \\
4\end{array}$ & $\begin{array}{r}98, \\
4\end{array}$ & $\begin{array}{r}89, \\
6\end{array}$ & $\begin{array}{r}99 \\
8\end{array}$ \\
\hline March & 100,8 & $\begin{array}{r}11 \\
2,7\end{array}$ & $\begin{array}{r}101 \\
, 2\end{array}$ & $\begin{array}{r}10 \\
1,0\end{array}$ & $\begin{array}{r}101 \\
, 1\end{array}$ \\
\hline I quarter & 100,1 & $\begin{array}{r}83, \\
1\end{array}$ & & & \\
\hline April & 102,3 & $\begin{array}{r}97 \\
7\end{array}$ & $\begin{array}{r}100 \\
, 7\end{array}$ & $\begin{array}{r}98 \\
7\end{array}$ & $\begin{array}{r}101 \\
, 8\end{array}$ \\
\hline May & 105,6 & $\begin{array}{r}10 \\
1,2\end{array}$ & $\begin{array}{r}101 \\
, 5\end{array}$ & $\begin{array}{r}99 \\
9\end{array}$ & $\begin{array}{r}103 \\
, 3\end{array}$ \\
\hline June & 103,5 & 10 & 99 & 10 & 102 \\
\hline
\end{tabular}




\begin{tabular}{|c|c|c|c|c|c|}
\hline & \multicolumn{5}{|c|}{ In $\%$ to } \\
\hline & \multirow{2}{*}{$\begin{array}{c}\text { By } \\
\text { corresponding } \\
\text { period of a } \\
\text { previous year }\end{array}$} & \multicolumn{2}{|c|}{ To previous period } & \multicolumn{2}{|c|}{$\begin{array}{c}\text { To the average monthly } \\
\text { value of } 2014\end{array}$} \\
\hline & & Actually & $\begin{array}{c}\text { With an } \\
\text { exception } \\
\text { seasonal } \\
\text { and } \\
\text { calendar } \\
\text { factors }\end{array}$ & Actually & $\begin{array}{l}\text { With an } \\
\text { exception } \\
\text { seasonal } \\
\text { and } \\
\text { calendar } \\
\text { factors } \\
\end{array}$ \\
\hline & & 1,7 & 3 & 1,6 & ,6 \\
\hline II quarter & 103,8 & $\begin{array}{l}10 \\
6,9\end{array}$ & & & \\
\hline $\begin{array}{l}\text { I half a } \\
\text { year }\end{array}$ & 102,0 & & & & \\
\hline July & 101,1 & $\begin{array}{r}97, \\
5\end{array}$ & $\begin{array}{r}98, \\
7\end{array}$ & $\begin{array}{r}99, \\
0\end{array}$ & $\begin{array}{r}101 \\
, 2\end{array}$ \\
\hline August & 101,5 & $\begin{array}{r}10 \\
2,0\end{array}$ & $\begin{array}{r}100 \\
, 4\end{array}$ & $\begin{array}{r}10 \\
1,0\end{array}$ & $\begin{array}{r}101 \\
, 6\end{array}$ \\
\hline September & 100,9 & $\begin{array}{r}10 \\
1,0\end{array}$ & $\begin{array}{r}99 \\
4\end{array}$ & $\begin{array}{r}10 \\
2,0\end{array}$ & $\begin{array}{r}101 \\
, 1\end{array}$ \\
\hline $\begin{array}{c}\text { III } \\
\text { quarter }\end{array}$ & 101,4 & $\begin{array}{l}10 \\
0,7\end{array}$ & & & \\
\hline $\begin{array}{l}\text { January - } \\
\text { September }\end{array}$ & 101,8 & & & & \\
\hline October & 100,0 & $\begin{array}{r}10 \\
5,7\end{array}$ & $\begin{array}{r}99 \\
8\end{array}$ & $\begin{array}{r}10 \\
7,8\end{array}$ & $\begin{array}{r}100 \\
, 9\end{array}$ \\
\hline November & 96,4 & $\begin{array}{r}99 \\
8\end{array}$ & $\begin{array}{r}98, \\
6\end{array}$ & $\begin{array}{r}10 \\
7,6\end{array}$ & $\begin{array}{r}99 \\
5\end{array}$ \\
\hline December & 98,5 & $\begin{array}{r}10 \\
8,2\end{array}$ & $\begin{array}{r}100 \\
, 4\end{array}$ & $\begin{array}{r}11 \\
6,4\end{array}$ & $\begin{array}{r}99 \\
9\end{array}$ \\
\hline IV quarter & 98,3 & $\begin{array}{r}10 \\
9,9\end{array}$ & & & \\
\hline Year & 101,0 & & & & \\
\hline
\end{tabular}

The indices of industrial production in Russia, given in the table, suggest that, in General, from 2014 to 2017, the indicators of industry show a slight increase.

As for the output of certain types of industrial products, the indicators of extractive industries, in particular: coal, gas, coke, have been growing in recent years. However, oil production declined slightly. Production of cars and combines increased by more than $20 \%$ per year, and production of electric and diesel locomotives decreased by more than $10 \%$ per year from 2016 to 2017. The described trends are given in table 2[2].

Table 2. Production of certain types of industrial products in Russia

\begin{tabular}{|c|c|c|c|c|}
\hline & 2017 & $\begin{array}{c}\text { Dece } \\
\text { in }\end{array}$ & $\begin{array}{l}\text { ber } 2017 \\
\text { to }\end{array}$ & $\begin{array}{c}2017 \\
\text { in \% to }\end{array}$ \\
\hline & & $\begin{array}{c}\text { December } \\
2016\end{array}$ & $\begin{array}{c}\text { November } \\
2017\end{array}$ & 2016 \\
\hline Coal, million tonnes & $\begin{array}{r}41 \\
0\end{array}$ & $\begin{array}{r}101 \\
3\end{array}$ & $\begin{array}{r}102 \\
4\end{array}$ & $\begin{array}{r}106, \\
4\end{array}$ \\
\hline
\end{tabular}




\begin{tabular}{|c|c|c|c|c|}
\hline & \multirow[t]{2}{*}{2017} & \multicolumn{2}{|c|}{$\begin{array}{l}\text { December } 2017 \\
\text { in } \% \text { to }\end{array}$} & \multirow{2}{*}{$\begin{array}{c}2017 \\
\text { in \% to } \\
2016\end{array}$} \\
\hline & & $\begin{array}{l}\text { December } \\
2016\end{array}$ & $\begin{array}{c}\text { November } \\
2017\end{array}$ & \\
\hline Crude oil, including gas condensate, & $\begin{array}{r}54 \\
6 \\
\end{array}$ & 97,8 & $\begin{array}{r}103, \\
5 \\
\end{array}$ & 99,7 \\
\hline million tons & $\begin{array}{r}60 \\
4\end{array}$ & 95,4 & $\begin{array}{r}105, \\
1\end{array}$ & $\begin{array}{r}108, \\
7\end{array}$ \\
\hline Combustible natural gas (natural gas), & $\begin{array}{r}28, \\
0\end{array}$ & 93,3 & $\begin{array}{r}101 \\
3\end{array}$ & 96,2 \\
\hline billion $\mathrm{m} 3$ & $\begin{array}{r}28 \\
4 \\
\end{array}$ & 97,2 & $\begin{array}{r}103, \\
6\end{array}$ & 99,7 \\
\hline $\begin{array}{l}\text { Coke and semi-coke of coal, million } \\
\text { tons }\end{array}$ & $\begin{array}{r}38, \\
0\end{array}$ & 99,8 & $\begin{array}{r}108, \\
5\end{array}$ & 98,4 \\
\hline Oil received for processing & $\begin{array}{r}11 \\
3\end{array}$ & 111, & $\begin{array}{r}107 \\
5\end{array}$ & $\begin{array}{r}104, \\
8\end{array}$ \\
\hline (crude oil), MT & 7,3 & 64,2 & 67,4 & $\begin{array}{r}120 \\
4 \\
\end{array}$ \\
\hline Motor gasoline, million tons & 1,4 & $\begin{array}{r}107 \\
2\end{array}$ & 80,8 & $\begin{array}{r}121 \\
0\end{array}$ \\
\hline Tubes, hollow profiles and their & $\begin{array}{r}22 \\
5\end{array}$ & $\begin{array}{r}133 \\
3\end{array}$ & 250 & 88,2 \\
\hline steel fittings, million tons & $\begin{array}{r}19 \\
7 \\
\end{array}$ & $\begin{array}{r}105 \\
3 \\
\end{array}$ & $\begin{array}{r}125, \\
0\end{array}$ & 88,7 \\
\hline Grain harvesters, thousand pieces & $\begin{array}{r}96 \\
3 \\
\end{array}$ & 81,7 & 88,8 & $\begin{array}{r}149, \\
1\end{array}$ \\
\hline Cars, million units & $\begin{array}{l}10 \\
91\end{array}$ & 96,9 & $\begin{array}{r}108, \\
0\end{array}$ & $\begin{array}{r}100, \\
1\end{array}$ \\
\hline Electric transmission, pieces & $\begin{array}{l}12 \\
58 \\
\end{array}$ & 89,6 & $\begin{array}{r}116, \\
6 \\
\end{array}$ & 99,1 \\
\hline
\end{tabular}

The positive aspects of the development of certain industries of the Russian Federation include the following:

1. The heavy industry is developing very actively-the production of motor vehicles, trailers and semi-trailers $(+13.5 \%)$, as well as the production of machinery and equipment $(+8.2 \%)$. For a long time, the mechanical engineering industry remained lagging behind and this was not given due attention. However, the measures of state support served as an incentive for development. Evidence of this is the fact that by the end of 2015 the production of motor vehicles, trailers and semi - trailers decreased by $23.1 \%$, and the production of machinery and equipment-by $4.3 \%$. Only in 2016 , the situation began to improve. There was a significant increase in the production of grain harvesters $(+46.1 \%)$, which allowed to replace foreign analogues, as well as the production of freight cars $(+28.8 \%)$. The growth of production of trucks was $6,9 \%$. At the same time, Russian production can fully provide the Russian market with these products. The share of imports of these products has decreased significantly. For example, the share of imported harvesters in the market in February decreased to 5.2\% compared to $14.2 \%$ in February 2016.

2. Growth is observed in the light industry. First of all, it is garment production $(+8.5 \%)$, leather and leather goods production $(+7.8 \%)$ and slightly increased textile production $(+3.8 \%)$. Three of these components characterize the light industry of Russia. In other words, it has been developing quite well in recent months. There is an increase in the production of shoes (in February $+3.3 \%$ ), caused by domestic demand. Despite the growth, a significant problem in the production of textiles is the low quality of products, which does not allow to increase exports [1]. 
3. The third important problem, which negatively affects the development of industry, is underdeveloped research work in this area. Imperfect research and production base and the lack of research companies that are engaged in the development and implementation of modern technologies and developments in the industry, leads to deplorable consequences and reduces the rate of production growth.

4. The fourth most important problem is the sharp outflow of qualified personnel and the deterioration of the social situation in enterprises. The shortage of personnel has a severe impact on the development of the industrial complex.

We presented the indicators of industry development in Russia as a whole [3]. As for individual industrial enterprises, the following system of performance indicators can be defined:

1) summary indicators:

- net production per unit resource cost;

- $\quad$ profit per unit of total cost;

- $\quad$ production profitability;

- $\quad$ costs per 1 ruble of commodity production;

- $\quad$ share of production growth due to intensification of production;

- $\quad$ economic effect of using a unit of production;

2) indicators of efficiency of use of labour (personnel):

- the growth rate of labor productivity;

- $\quad$ share of increase in production due to increase in labor productivity;

- absolute and relative release of employees;

- utilization factor of useful working time Fund;

- $\quad$ labor input per unit of output;

- $\quad$ wage capacity unit;

3) performance indicators of the use of production assets:

- the total return on assets;

- $\quad$ performance of the active part of fixed assets;

- $\quad$ profitability of fixed assets;

- the capital intensity per unit of output;

- material intensity per unit of output;

- utilization factor of the most important raw materials and materials;

4) indicators of efficiency of use of funds:

- $\quad$ turnover of working capital;

- $\quad$ return on working capital;

- $\quad$ relative release of working capital;

- $\quad$ specific capital investments (per unit of capacity or output growth));

- $\quad$ profitability of capital investments;

- $\quad$ payback period of capital investments, etc.

Ways to improve the economic efficiency of production - a set of specific measures to increase the efficiency of production in specified directions.

The main ways to improve the economic efficiency of production:

- reduced labor intensity,

- improving productivity,

- reduction of material consumption of products,

- rational use of natural resources,

- reduction of production capacity,

- activation of investment activity of enterprises.

An important factor in improving the efficiency of the enterprise is scientific and technological progress. 
In modern conditions need a revolutionary, qualitative change, the transition to fundamentally new technologies, to technology of future generations, a fundamental re all branches of the national economy on the basis of the latest achievements of science and technology.

Fundamental changes in technology, the mobilization of all, not only technical but also organizational, economic and social factors, will create conditions for a significant increase in productivity.

It is necessary to ensure the introduction of the latest technology, widely used in the production of advanced forms of scientific organization of labor, improve its rationing, to achieve the growth of the culture of production, strengthening the order and discipline.

One of the important factors of intensification and increase of efficiency of production of the enterprises is the mode of economy. Resource conservation must become a critical source for meeting the growing demand for fuel, energy, raw materials and materials.

Improving the efficiency of production depends on the better use of fixed assets.

It is necessary to use the created production potential more intensively, to achieve rhythm of production, the maximum loading of the equipment, to considerably increase replacement of its work and on this basis to increase volume of production from each unit of the equipment, from each square meter of the floor space.

Organizational and economic factors play an important role in improving production efficiency. Especially increases their role with the increase of social production the increasing complexity of economic relations.

It requires further development and improvement of the production social infrastructure, which has a significant impact on the level of production efficiency.

In management - is to improve the forms and methods of management, planning, economic stimulation of the entire economic mechanism.

In the same group of factors are widely used multiple levers of economic calculation and material incentives, liability and other self-supporting economic incentives.

In the development of economic and social development plans, the main attention is paid to improving the efficiency of production, i.e. increasing the production of highquality competitive products with the most efficient use of labor, material and financial resources.

The planning of economic efficiency indicators of production is based on the results of the development of other sections of the economic and social development plan: production and services, scientific and technical development, improvement of production and management, labor and personnel, cost, profit and profitability, capital construction.

A special place in the intensification of the economy of the enterprise, reducing the specific consumption of resources belongs to improving the quality of products. This task should be the subject of constant attention and monitoring, the main factor in assessing the activities of each labor collective.

Among all the factors of increasing the efficiency and intensification of production, the decisive place belongs to the privatization of the economy, scientific and technological progress and the intensification of human activities, strengthening the personal factor (communication, cooperation, coordination, commitment), increasing the role of people in the production process. All other factors are interdependent with those decisive factors.

Depending on the location and scope of implementation, ways to improve efficiency are divided into:

- national (state),

- sectoral,

- territorial,

- intraproductive. 
In the economic science of countries with developed market relations, these ways are divided into two groups:

- internal and external, or factors affecting changes in profits and controlled by the firm and uncontrolled factors that the firm can only adjust to.

- the second group of factors is specific market conditions, prices for products, raw materials, energy, exchange rates, Bank interest, the system of state orders, taxation, tax benefits, etc.

The most diverse group of internal factors on the scale of the enterprise, Association, firm. Their number and content are specific to each company depending on its specialization, structure, time of operation, current and future challenges. They cannot be unified and unified for all enterprises.

Quantitative assessment of in-production factors is given in terms of technical and organizational improvement of production-reduction of labor intensity and productivity growth, reduction of material consumption and saving of material resources, saving from reduction of production costs and increase of profit and profitability, increase of production capacity and output, economic effect from implementation of measures, as well as specific sizes of capital costs and terms of implementation of measures.

Management of efficiency and profitability of production in the conditions of the market assumes, both development and implementation of current plans, and development of forecasts, control and the analysis of their realization. At the same time, it is important to take into account the factor of time: the time that is necessary for a new product or service to enter the market; the time necessary for the development and implementation of new ideas, inventions and rationalization proposals, the development of the production of new products and its removal from production and replacement with new or significantly modernized products

In conclusion, it would be useful to draw the following conclusions:

1. Industry plays a huge role in the Russian economy and is formed by a wide sector of industries and complexes.

2. The Russian industry as a whole has demonstrated positive dynamics in recent years.

3. Despite the positive trends, Russian industrial enterprises are experiencing a number of difficulties and problems that reduce the effectiveness of their activities.

4. There are a large number of measures, the implementation of which will improve the economic efficiency of domestic industrial enterprises.

\section{References}

1. Improving the efficiency of domestic industry in the sustainable development model: collective monograph / edited by Veselovsky M. Ya., Kirova I. V., Nikonorova A.V. I - M.: Publishing house "Scientific consultant" (2015) - 252 p.

2. Official website of the Federal state statistics service. http://www.gks.ru/

3. Mechikova M. N. Structural-level approach to the development of the institutional and economic mechanism of industrial policy: author. dis. ... kand. Ekon. sciences'. Rostov-on -Don. (2011) -28 p. 